\title{
Perineal stapled rectal resection without a contour transtar: a modified approach
}

\author{
Gökhan Özüner ${ }^{1}$, Çiğdem Benlice ${ }^{2}$ \\ ${ }^{1}$ New York Presbyterian, Cornell Brooklyn Methodist Hospital, New York, USA \\ ${ }^{2}$ Department of Colorectal Surgery, Cleveland Clinic, Digestive Disease Institute, Cleveland, USA
}

\section{ABSTRACT}

Perineal stapled prolapse resection is a novel approach for treating rectal prolapse in elderly and frail patients. This study aimed to report a modified technique using only a straight linear stapler. A 94-year-old female with 15-cm full thickness rectal prolapse was treated using a linear cutter in the left and right lateral quadrants, and then resection was completed by using the same instrument in the anterior and posterior flaps. The procedure was performed under local anesthesia and in a prone jackknife position. There was no morbidity or mortality, and the patient was discharged on postoperative day 2. Follow-up at 9 months revealed no recurrent prolapse, and the patient was asymptomatic. This technique is easy, safe, and fast to perform without using contour transtar (Ethicon Endo-Surgery, Cincinnati, $\mathrm{OH}$ ).

Keywords: Contour transtar, rectal prolapses, stapled resection

Cite this article as: Özüner G, Benlice C.. Perineal stapled rectal resection without a contour transtar: a modified approach. Turk J Surg 2019; 35 (1):70-73

\section{Corresponding Author}

Gökhan Özüner

E-mail: gozuner@gmail.com

Received: 13.05.2016

Accepted: 03.03.2017

Available Online Date: 03.01.2018

OCopyright 2019 by Turkish Surgical Society Available online at www.turkjsurg.com

DOI: $10.5578 /$ turkjsurg.3613

\section{INTRODUCTION}

The preferred treatment for frail and elderly patients with rectal prolapse is a perineal approach. Various techniques including Altemeier et al. and Delorme have been more commonly performed in such patients with full rectal prolapse $(1,2)$. In 2008, Scherer et al. described a new perineal approach [perineal stapled prolapse (PSP) resection] and a further refinement of this technique was described by Romano et al. in 2009 (3,4). Main drawbacks of PSP are the high cost of two different kinds of staplers employed and a potential risk of damaging adherent peritoneal tissue.

\section{CASE REPORT}

A 94-year-old patient presented with a 3-month history of rectal pressure, bright red bleeding per rectum and a prolapsing mass that came out of her rectum after bowel movements. Her past medical history was significant for hypertension and degenerative joint disease. On examination, a 15-cm reducible rectal prolapse was noted. The patient denied symptoms of constipation or incontinence. After alternative procedures were discussed and lack of long-term data about PSP was disclosed, the patient gave consent for PSP. A full bowel prep was conducted and perioperative antibiotics were administered.

\section{Surgical Technique}

The patient underwent colonoscopy before the procedure with conscious sedation in the left lateral position. Subsequently, she was put in a prone jackknife position. A 10-inch roll was put under her hips and the buttocks were taped apart. This position is optimal as it gives good visualization and any potential organ in the pouch of Douglas that is pushed cranially away resulting from the prolapse. The patient received 1\% lidocaine in 1:200.000 epinephrine as anesthetic, which was infiltrated with a 27-gauge needle to the perianal area and anal canal (total $22 \mathrm{cc}$ of local anesthetic was used). The prolapse was corrected with Babcock clamps and bimanually examined to ensure that there were no intraperitoneal organs between the walls of the rectum. A linear straight stapler was used to divide the prolapse in the right and left lateral quadrants approximately $2 \mathrm{~cm}$ above the dentate line (Figures 1,2). After the stapler was fired, a 2-0 Vicryl suture (Ethicon Inc;; Somerville, NJ) was placed at the end of the staple line in each quadrant (Figure 3). Subsequently, the flaps were held and gently pulled with the Babcock clamp; then first the posterior and then 


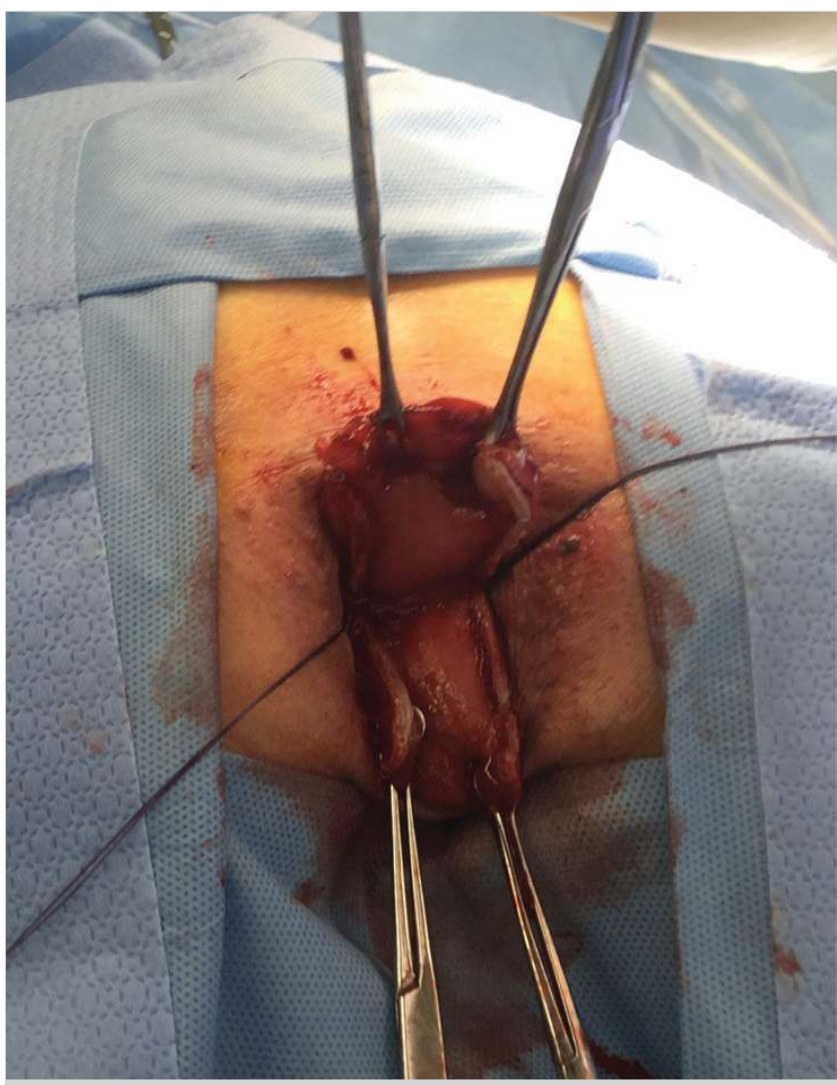

Figure 1. Division of the prolapses through the right and left quadrants.

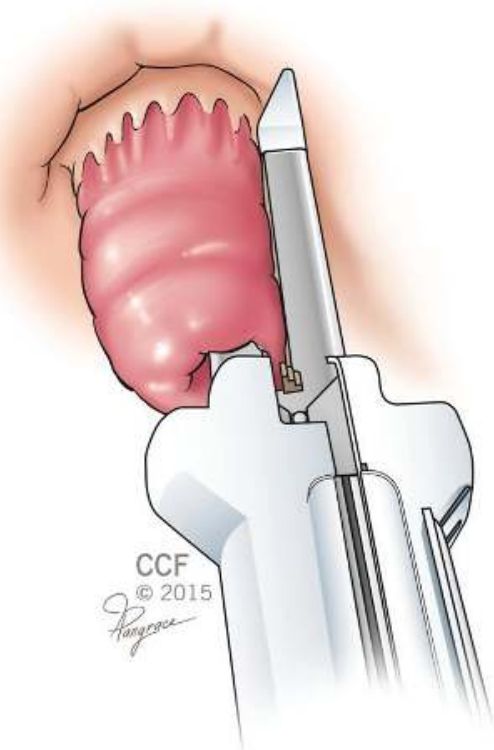

Figure 2. Division of the prolapses through the right and left quadrants.

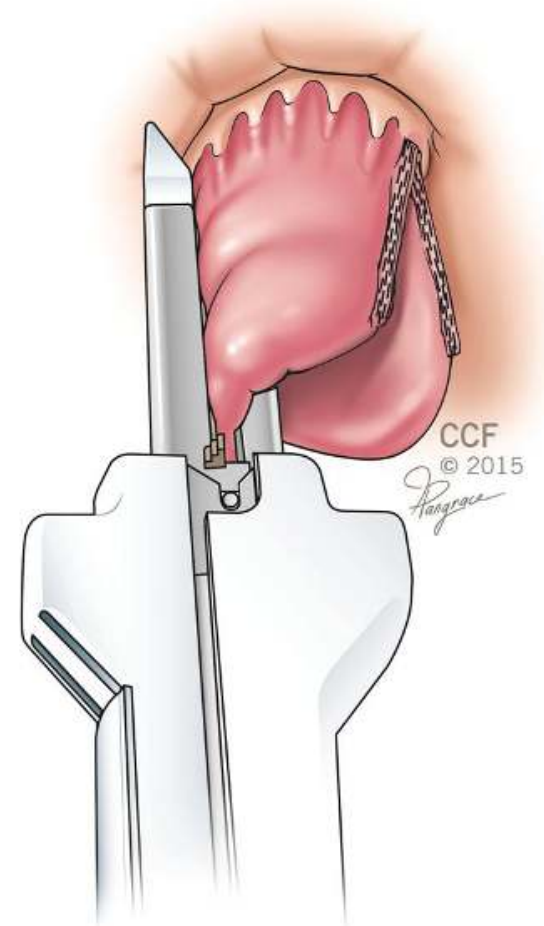

Figure 3. Placement of sutures at the end of staple lines in each quadrant.
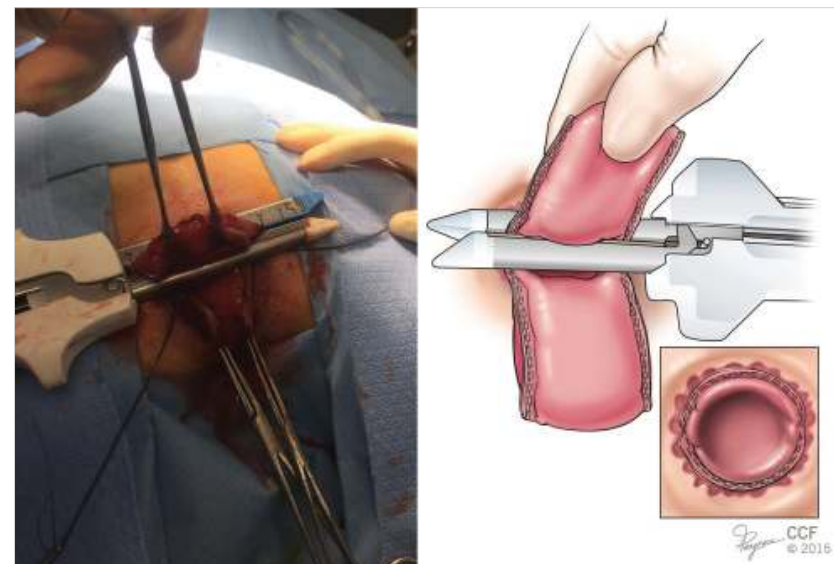

Figure 4. Division of the posterior and anterior flaps with linear stapler.

the anterior flap was again divided with the linear stapler (Figure 4). The stapler was positioned $2 \mathrm{~cm}$ proximal to the dentate line. Before stapling and cutting the anterior flap, the back wall of the vagina was checked. During this procedure, traction of the anterior flap with the Babcock clamp was maintained. After the last firing, the neorectum fell back. After each firing, the integrity of the staple line was checked. We routinely use a lighted bivalve anoscope and over-suture the staple line with a 2-0 Vicryl suture. 
At the end of the procedure, a rigid proctoscopy was performed along with irrigation and suction. Postoperatively, a regular diet was administered.

\section{RESULTS}

The operative time lasted $48 \mathrm{~min}$. No morbidity occurred, and the patient was discharged after 2 days. At follow-up of 9 months after surgery, no recurrent prolapse or incontinence was noted.

\section{DISCUSSION}

Rectal prolapse in old, frail patients with multiple comorbid conditions can be challenging. Perineal procedures are generally preferred in this group of patients but the optimum procedure in terms of safety, recurrence, and functional results is still debated. After Scherer described PSP in 2008 and a modification of this technique was reported by Romano in 2009, various authors have reported their experiences in this relatively new technique (3-7). The safety, technical ease, and comparable outcome have been confirmed in these reports (3-8).

A major concern with this technique has been the potential vaginal and even small bowel injury, especially in women with a history of hysterectomy (9). A steep Trendelenburg position in a patient who is in a lithotomy position and checking the vagina has been recommended to prevent such injuries. An alternative of using laparoscopic guidance during anterior stapling has been suggested as well. In our technique and in Romano's modification, the patient was operated in a prone jackknife position, which forces the small bowel to migrate cranially and away from the prolapse and minimizes this potential complication. In addition, the vagina falls away from the prolapse by gravity. Another concern with this technique is the increased cost and whether the cost-to-benefit ratio of PSP is justified.

The cost of linear staplers and a contour stapler varies due to contracts and geographic sites. However, the cost of four firings of a linear stapler compared to two firings of a linear stapler in addition to two firings of a contour transtar (Ethicon Endo-Surgery, Cincinnati, $\mathrm{OH}$ ) is less. In our technique, contour transtar was not used but only a linear stapler with multifirings was, which decreased the cost by more than $50 \%$. Although such cost saving is significant, it needs to be determined whether this overall cost is offset by the shorter operating and hospitalization time.

In addition, we performed this procedure under local anesthesia, in this way the patient was not subject to potential complications of general or spinal anesthesia.

\section{CONCLUSION}

The procedure is easy to perform and is suitable in a select group of frail, elderly patients. Long-term recurrence rate needs to be analyzed perhaps in a multicenter study.

Informed Consent: Written informed consent was obtained from patient who participated in this study.

Peer-review: Externally peer-reviewed.

Author Contributions: Concept - G.Ö.; Design - G.Ö.; Supervision - G.Ö.; Resource - G.Ö., Ç.B.; Materials - G.Ö., Ç.B.; Data Collection and/or Processing - G.Ö., Ç.B.; Analysis and/or Interpretation - G.Ö., Ç.B.; Literature Search - G.Ö., Ç.B.; Writing Manuscript - G.Ö., Ç.B.; Critical Reviews - G.Ö., Ç.B.

Acknowledgements: The authors thank to Joe Pangrace.

Conflict of Interest: No conflict of interest was declared by the authors.

Financial Disclosure: The authors declared that this study has received no financial support.

\section{REFERENCES}

1. Altemeier WA, Culbertson WR, Schowengerd CJ, Hunt J. Nineteen years experience with the one stage perineal repair in rectal prolapsed. Ann Surg 1971; 173: 993-1006. [CrossRef]

2. Delorme E. Sur le traitement des prolapsus du rectum totaux pour l'excision de la muqueuse rectal ou rectocolique. Bull Mem Soc Chir Paris 1900; 26: 499-578.

3. Scherer R, Marti L, Hetzer FH. Perineal stapled prolapse resection: a new procedure for external prolapse. Dis Colon Rectum 2008; 51: 1727-30. [CrossRef]

4. Romano G, Bianco F, Caggiano L. Modified perineal stapled rectal resection with contour transtar for full-thickness rectal prolapse. Colorectal Dis 2009; 11:878-81. [CrossRef]

5. Mistrangelo M, Tonello P, Allaix ME, Borroni R, Canavesio N, Corno F. Perineal Stapled prolapse resection for complete external rectal prolapse: preliminary experience and literature review. Dig Surg 2012; 29: 87-91. [CrossRef]

6. Tschuor C, Limani P, Nocito A, Dindo D, Clavien PA, Hahnloser D. Perineal stapled prolapse resection for external rectal prolapse: is it worth while in the long-term? Tech Coloproctol 2013; 17:537-40. [CrossRef]

7. Ram E, Krissi H, Zbar A, Atar E, Joubran S, Rath-Wolfson LR. Perineal stapled prolapse resection (PSPR) in elderly patients for external rectal prolapse: early experience. Tech Coloproctol 2014; 18: 1003-7. [CrossRef]

8. Karahasanoğlu T, Hamzaoğlu i, Baca B, Engin P, Onur E, Memisoglu K, et al. Laparoscopic surgery in the treatment of rectal prolap. Kolon Rektum Hast Derg 2007; 17: 186-90.

9. Pescatori $M$. The stapled resection of full thickness external prolapse response to Romano. Colorectal Dis 2010; 12: 388-9. [CrossRef] 
OLGU SUNUMU-ÖZET

Turk J Surg 2019; 35 (1): 70-73

Kontur transtar kullanılmadan perineal stapler rektal rezeksiyon: Modifiye yaklaşım

Gökhan Özüner ${ }^{1}$, Çiğdem Benlice ${ }^{1}$

${ }^{1}$ New York Presbyterian, Cornell Brooklyn Methodist Hospital, New York, USA

${ }^{2}$ Department of Colorectal Surgery, Cleveland Clinic, Digestive Disease Institute, Cleveland, USA

ÖZET

Perineal staple prolapsus (PSP) rezeksiyonu yaşı ve zayıf hastalarda rektal prolapsus tedavisi için yeni bir yaklaşımdır. Bu çalışmada, sadece düz çizgisel stapler (straight linear stapler) kullanarak modifiye teknik bildiriyoruz. Doksan dört yaşındaki bir kadın hastanın $15 \mathrm{~cm}$ tam kat rektal prolapsusu anterior ve posterior kapakları aynı enstrüman ile sol ve sağ yan kadranda lineer kesici kullanılarak tedavi edildi ve daha sonra rezeksiyonu tamamlandı. İ̧̧lem, lokal anestezi altında ve yüzüstü jackknife pozisyonda yapıldı. Postoperatif dönemde morbidite veya mortalite bildirilmedi ve hasta ikinci günde taburcu edildi. Dokuz ay takibi tamamlayan hastada rekürrens bildirilmedi. Bu teknik gerçekleştirmesi kolay, güvenli, hızlı ve kontur TranStar kullanılmadığı bir yöntemdir.

Anahtar Kelimeler: Transtar kontur, rektal prolapsus, stapler rezeksiyon

Doi: $10.5578 /$ turkjsurg. 3613 